\title{
In Vivo Binding of [18 F] altanserin to Rat Brain 5HT2 Receptors: A Film and Electronic Autoradiographic Study
}

\author{
Biver F,(1)(2) Lotstra F, (1) Monclus M,(2) Dethy S, (2) . Damhaut P, (2) Wikler D ,(2) Luxen A, (2) \\ and Goldman $\mathrm{S}(2)$ \\ (1) PSYCHIATRY DEPARTMENT \\ ( 2) PET-BIOMEDICAL CYCLOTRON UNIT, ERASME HOSPITAL, FREE UNIVERSITY OF \\ BRUSSELS, BRUSSELS, BELGIUM
}

\begin{abstract}
To further validate its use in positron emission tomography (PET), we studied the binding of $\left[{ }^{18} \mathrm{~F}\right]$ altanserin, a specific $5 \mathrm{HT}_{2}$ radioligand, in the rat brain using in vivo autoradiography. Distribution of $\left[{ }^{18} \mathrm{~F}\right]$ altanserin binding was comparable to the in vitro mapping of $5 \mathrm{HT}_{2}$ receptors reported in the literature. Selective displacers were used to test the reversibility and the selectivity of this radioligand. Specific binding of $\left[{ }^{18} \mathrm{~F}\right]$ altanserin in the rat frontal cortex was quantified by direct counting with an electronic imaging system and by quantification on digitalized autoradiograms. Close results of about $30 \mathrm{pmol} / \mathrm{g}$ were obtained with both methods. Our data confirmed that $\left[{ }^{18} \mathrm{~F}\right]$ altanserin is a valid tracer for $5 \mathrm{HT}_{2}$ receptors binding studies.
\end{abstract}

KEYWORDS. [ ${ }^{18}$ F]Altanserin, $5 \mathrm{HT}_{2}$ Receptors, Rat, Brain, Autoradiography, PET

\section{INTRODUCTION}

$\left[{ }^{18} \mathrm{~F}\right]$ Altanserin has been proposed as a new radiotracer for the study of the type 2-serotoninergic $\left(5 \mathrm{HT}_{2}\right)$ receptors using positron emission tomography (PET). In vitro, altanserin binds with high affinity to the $5 \mathrm{HT}_{2}$ receptors $(\mathrm{Ki}: 0.13 \mathrm{nM})$ and does not bind to $5 \mathrm{HT}_{1}$ receptors $(\mathrm{Ki}>1400 \mathrm{tiM})$. This p-fluorophenylketone derivative has a good in vitro specificity; Ki values (nM) measured for $\mathrm{D}_{2}$ dopaminergic, $\alpha_{1}$ adrenergic and $\mathrm{H}_{1}$ histaminergic receptors are respectively $62,4.6$, and $7.8 \mathrm{nM}(5)$.

Data on the in vivo biodistri-bution, affinity and specificity characteristics of $\left[{ }^{18} \mathrm{~F}\right]$ altanserin obtained in the rat indicated that this tracer may be successfully applied to PET imaging (4). We have developed a semi-automated method of synthesis of $\left[{ }^{18} \mathrm{~F}\right]$ altanserin which allows the production of high specific activity tracer and we have proposed a model for PET quantification of the $5 \mathrm{HT}_{2}$ receptors in the human brain using this tracer (2). We have here used the in vivo autoradiographic method to precisely study the distribution of $\left[{ }^{18} \mathrm{~F}\right]$ altanserin in the rat brain and to further define the specificity of this radiotracer. We also tested the use of an electronic imaging system for the quantification of this PET tracer distribution in in vivo experiments.

\section{MATERIALS AND METHODS}

\section{RADIOSYNTHESIS OF [ ${ }^{18}$ F]ALTANSERIN.}

Altanserin was supplied by Janssen Pharmaceutica NV (Beerse, Belgium). $\left[{ }^{18}\right.$ F]Altanserin (Fig. 1) was synthetized in an semi-automated system using the method previously described in the literature (4) and modified in our laboratory (8). Specific activity ranged from $37.10^{3} \mathrm{MBq} / \mu 1$ to $111.10^{3}$ $\mathrm{MBq} / \mu \mathrm{l}(1-3 \mathrm{Ci} / \mu \mathrm{mol})$. 


\section{ANIMAL EXPERIMENTS.}

The study was performed in compliance with the code of practice of the Free University of Brussels. Male Wistar rats (300 - $400 \mathrm{~g})$ were anesthetized with Nembutal $(0.05$

$\mathrm{mg} / 100 \mathrm{~g}$, i.p.). Rats were sacrificed by decapitation one hour after intravenous injection of about 15 $\mathrm{mCi} / \mathrm{kg}$ of $\left[{ }^{18} \mathrm{~F}\right]$ altanserin. Brains were carefully removed from the skull and rapidly frozen on dry ice (carbon dioxide). Sagittal sections (20- $\mu \mathrm{m}$ thick) were cut using a Reichert-Jung 2700 microtome cryostat. The sections were mounted on microscope slides and apposed for at least 10 half-lives to Kodak SB5 films in X-ray cassettes. The exposed autoradiographic films were developed for $2 \mathrm{~min}$ in Kodak LX-24 and fixed for $10 \mathrm{~min}$ in Kodak AL4 Fixer. Autoradiograms were quantified using a video-densitometry digital-film analyser. Digital sampling of transmitted light intensities through the autoradiograms were performed with 256 gray levels according to a 256 X 256 array size. Regions of interest were drawn on these digitalized images to calculate regional optical densities in triplicate. The reversibility of the binding was tested, in duplicate, by ketanserin injection $(4 \mathrm{mg} / \mathrm{kg}$; Dupont de Nemours, Belgium) 30 min after $\left[{ }^{18} \mathrm{~F}\right]$ altan-serin injection. In order to evaluate binding inhibition, unla-belled selective displacers were injected before $\left[{ }^{18} \mathrm{~F}\right]$ altanserin administration: prazosin $\left(\alpha_{1}\right.$ antagonist; $2 \mathrm{mg} / \mathrm{kg}$; Sigma Chemical Co, USA), sulpiride (D 2 antagonist; $40 \mathrm{mg} / \mathrm{kg}$; Sigma Chemical Co, USA), triprolidine ( $\mathrm{H}_{1}$ antagonist; $12 \mathrm{mg} / \mathrm{kg}$; Sigma Chemical Co, USA), 8-OH-DPAT (5HT $1 \mathrm{~A}$ agonist; $2 \mathrm{mg} / \mathrm{kg}$; Cookson Chemicals LTD, England), sumatriptan (5HT $1 \mathrm{D}$ antagonist; $1 \mathrm{mg} / \mathrm{kg}$; Glaxo Group Research, UK), mesulergin (5 $\mathrm{HT}_{2}$ and $5 \mathrm{HT}_{1 \mathrm{C}}$ antagonist; $10 \mathrm{mg} / \mathrm{kg}$; Sandoz NV, Belgium), ketanserin (5HT2 antagonist; $4 \mathrm{mg} / \mathrm{kg}$; Dupont de Nemours, Belgium), ondansetron (5HT, antagonist; $2.5 \mathrm{mg} / \mathrm{kg}$; Glaxo Group Research, UK) and citalopram (reuptake inhibitor; $4 \mathrm{mg} / \mathrm{kg}$; Lundbeck NV, Belgium).

In order to quantify the amount of tracer bound to brain sections of rats injected with [ $\left.{ }^{18} \mathrm{~F}\right]$ altanserin at high $(>0.9 \mathrm{Ci} / \mu \mathrm{mol})$ and low $(<0.2 \mathrm{Ci} / \mu \mathrm{mol})$ specific activity, a ${ }^{18} \mathrm{~F}$ scale in brain tissue was used.

Multiple solutions were prepared with different concentrations of $\left[{ }^{18} \mathrm{~F}\right]$ fluoride. Ten $\mu 1$ of the solutions were added to $0.5 \mathrm{~g}$ of rat brain homogenates. Brain homogenates were stirred and frozen in cylindrical microfuge tubes, then cut with the microtome cryostat $(20 \mu \mathrm{m})$ and mounted on microscope slides. Analysis was performed using two different system: (1) direct 10-min counting by the Packard's Instant Imager ${ }^{\mathrm{TM}}$, an electronic imaging system using the multiwire proportional counting readout technology (Packard Instrument Company, Meriden, CT, USA), and (2) image analysis of digitalized autoradiograms.

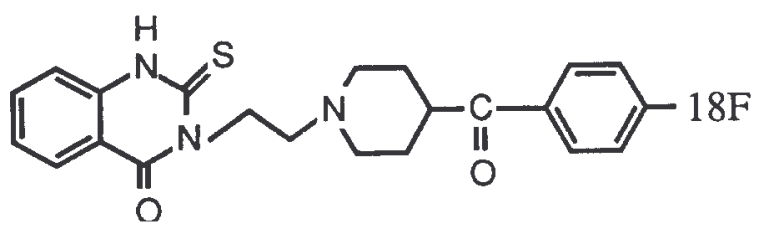

FIG. 1. Chemical structure of $\left[^{18}\right.$ F]altanserin.

Frontal specific binding (binding difference between high and low specific activity experiments) was calculated in duplicate (on three brain sections) and results were presented in pmole of $\left[{ }^{18} \mathrm{~F}\right]$ altanserin in $1 \mathrm{~g}$ of cortex and in percentage of the injected dose present in $1 \mathrm{~g}$ of cortex, normalized for a rat weight of $200 \mathrm{~g}(\% \mathrm{ID} / \mathrm{g})$. To allow future quantification of digitalized autoradiograms without preparation of standard brain homogenates, the same experiment was made using $\left[{ }^{14} \mathrm{C}\right]$ carbone microscales (Amersham RPA504L $\left[{ }^{14} \mathrm{C}\right]$ Micro-scales) and Amer-sham Hyper- $\beta$ max autoradiographic films, as proposed in the literature for $\left[{ }^{123} \mathrm{I}\right]$ iodine standards (3).

\section{RESULTS}

\section{$\left[{ }^{18}\right.$ F]ALTANSERIN DISTRIBUTION.}

Distribution of displaceable $\left[{ }^{18} \mathrm{~F}\right]$ altanserin binding appeared heterogeneous throughout the rat brain 
(Fig. 2). Binding in the cerebellum was almost undiscernable from the background and was considered as an indicator of non-specific binding. Levels of binding in different brain structures, relative to cerebellum binding, are presented in the table. The highest levels of binding were observed in the neocortex (mainly frontal), the piriform cortex, the claustrum and the anterior olfactory nuclei. Neocortical [ ${ }^{18} \mathrm{~F}$ ]altanserin binding presented a laminar distribution with dense labelling in profound neocortical [ $\left.{ }^{18} \mathrm{~F}\right]$ Altanserin Autoradiography in Rat Brain layers where the ratio to cerebellum binding reached a maximum value of 34 .
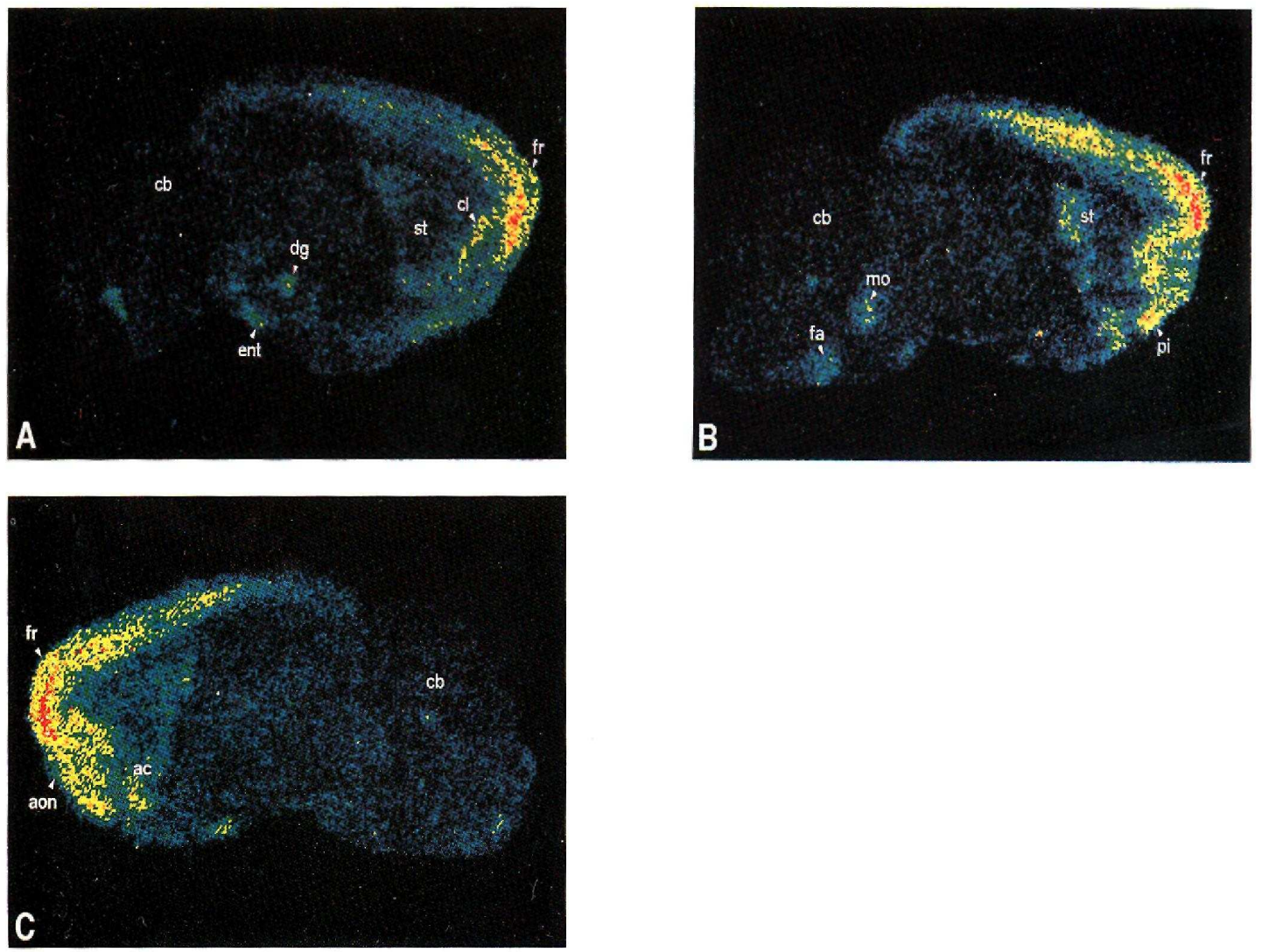

FIG. 2. $\left[{ }^{18}\right.$ F]Altanserin in vivo distribution in rat brain parasagittal sections cut at 3,90 $\mathrm{mm}$ from the mediosag-ittal plane (A), $2.40 \mathrm{~mm}$ from the mediosagittal plane (B) and $1.40 \mathrm{~mm}$ from the mediosagittal plane $(C)$. Fr $=$ frontal cortex; $c b$ - cerebellum; $d g=$ dentate gyrus; ent $=$ entorhinal cortex; st = striatum; $c l=$ claustrum; mo = motor trigeminal nucleus; fa = facial nucleus; $p i=$ piriform cortex; aon = anterior olfactory nuclei; ac = accumbens nucleus. 
TABLE 1. ${ }^{18}$ F]Altanserin Distribution in the Rat Brain $1 \mathrm{~h}$ Post Injection

Region to cerebellum activity ratio*

Lateral orbital frontal cortex

Agranular insular frontal cortex $\quad 9.4$

Frontal cortex, area $2 \quad 9.2$

Frontal cortex, area $1 \quad 8.0$

Hindlimb area of cortex $\quad 6.1$

Occipital cortex $\quad 3.7$

$\begin{array}{ll}\text { Claustrum } & 7.4\end{array}$

Piriform cortex $\quad 5.8$

Anterior olfactory nuclei $\quad 6.0$

Olfactory tubercle $\quad 4.8$

Caudate-putamen (dorsolateral) $\quad 5.3$

Caudate-putamen (anterior) $\quad 3.3$

Accumbens nucleus $\quad 5.7$

Thalamus $\quad 2.2$

Amygdalohippocampal area $\quad 3.8$

Zona incerta $\quad 3.4$

Dentate gyrus $\quad 5.6$

Entorhinal cortex $\quad 5.7$

Motor trigeminal nucleus $\quad 4.7$

Facial nucleus $\quad 4.4$

Pontine nuclei $\quad 3.6$

$* \mathrm{~N}=3$.

REVERSIBILITY AND SPECIFICITY OF $\left[{ }^{18}\right.$ F]ALTANSERIN BINDING.

$\left[{ }^{18} \mathrm{~F}\right]$ Altanserin binding was partially reversible by administration of ketanserin $(59 \%$ decrease of frontal to cerebellum ratio). In inhibition experiments, frontal to cerebellum ratio was decreased by $85 \%$ by mesulergin and by $82 \%$ by ketanserin. No other molecules reduced the frontal to cerebellum ratios to a value inferior to 2 standard deviations below the mean in the control rats.

${ }^{18}$ F]ALTANSERIN BINDING QUANTIFICATION.

Correlation between [ ${ }^{18} \mathrm{~F}$ ] fluoride concentrations in brain homogenates and their activity measured with the Instantlmager ${ }^{\mathrm{TM}}$ was linear and excellent $(\mathrm{r}>0.999)$. Using the electronic method, a value of $36.7 \pm 3.4 \mathrm{pmol} / \mathrm{g}$ of wet weight tissue was calculated for the specific binding of $\left[{ }^{18} \mathrm{~F}\right]$ altanserin in the frontal cortex, which corresponds to $0.71 \pm 0.17 \% \mathrm{ID} / \mathrm{g}$. On autoradiograms, $\left[{ }^{18} \mathrm{~F}\right]$ fluoride optical density measure $\left(\mathrm{F}_{\mathrm{OD}}\right)$ in brain homogenates is related to $\left[{ }^{18} \mathrm{~F}\right]$ fluoride radioactivity $\left(\mathrm{F}^{*}\right)$ according to a logarithmic curve:

$$
\mathrm{F}_{\mathrm{OD}}=\mathrm{a} \operatorname{LOG}\left(\mathrm{F}^{*}\right)+\mathrm{b}
$$

Two independant experiments provided very close values for the parameters $\mathrm{a}$ and $\mathrm{b}: \mathrm{a}=30.9$ and $\mathrm{b}=$ 68.9 (r: 0.975); $a=27.1$ and $b=55.9$ (r: 0.971). A value of $30.2 \pm 4.2 \mathrm{pmol} / \mathrm{g}$ of wet weight tissue was found for the specific binding of $\left[{ }^{18} \mathrm{~F}\right]$ altanserin in the frontal cortex, which corresponds to $0.56 \pm 0.16$ $\% \mathrm{ID} / \mathrm{g}$.

\section{$\left[{ }^{14}\right.$ C]CARBONE MICROSCALES FOR QUANTIFICATION.}

FOD measures are exponentially related to $\left[{ }^{14} \mathrm{C}\right]$ carbone microscales optical density measures $\left(\mathrm{C}_{\mathrm{OD}}\right)$ following the equation: 
$\mathrm{F}_{\mathrm{OD}}=\mathrm{p} 10 \mathrm{qcOD}$

Combining with equation $1, \operatorname{LOG}\left(\mathrm{F}^{*}\right)=\left(\mathrm{p} 10^{\mathrm{qCOD}}-\mathrm{b}\right) / \mathrm{a}$.

This equation may be used for quantification of autoradiograms produced by exposition of $18 \mathrm{~F}$ brain tissue. Our experiment provided the following values for the different parameters: $\mathrm{a}=32.4, \mathrm{~b}=65.9, \mathrm{p}$ $=0.029, \mathrm{q}=0.026$.

\section{DISCUSSION}

Our experiment demonstrates a distribution of $\left[{ }^{18} \mathrm{~F}\right]$ altanserin in vivo binding which globally corresponds to the mapping of $5 \mathrm{HT}_{2}$ receptors obtained by in situ hybridization or in vitro binding $(9$,

$7,6)$. The $5 \mathrm{HT}_{2}$ receptor densities in the frontal cortex obtained with $\left[{ }^{3} \mathrm{H}\right]$ ketanserin by in vitro autoradiography is reported to be $37.6 \pm 1.0 \mathrm{pmol} / \mathrm{g}(1)$, a value close to the amount of tracer bound in the cortex in our experiment. If the amount of receptors accessible in in vitro and in vivo experiments are similar, this fact indicates that the amount of tracer injected to obtain suitable autoradiograms was occupying a significant proportion of receptors so that pharmacological effects could have been produced. Considering the type of films used and the range of specific activities obtained with the method of radiosynthesis described, a reduction of the injected dose should result in an increase in signal to noise ratio, precluding valid quantification. Direct electronic imaging methods, which have much higher sensitivity than autoradiography, may help to reduce the amount of short half-live radioligands necessary to quantify the binding in different brain regions and allow therefore to perform these rat in vivo experiments with tracer amount of the PET radioligands. In our experiment, a direct electronic imaging method and the analysis of digitalized autoradiograms provided relatively similar values of $\left[{ }^{18} \mathrm{~F}\right]$ altanserin cortical specific binding. The differences found between the two methods were probably related to the differences in regions of interest delineation with the two systems and to technical sources of variability present in the autoradiographic method (homogeneity of autoradiogram, error in the logarithmic curve fitting, etc.). Compared to classical analysis of digitalized autoradiograms, the electronic imaging system does not require the preparation of standard brain homogenates for each experiment in order to perform absolute quantification of ligand binding. Furthermore, the linear function between electronic counting and regional radioactive content implies absence of exposure duration influence and, more importantly, proportional responses even in the presence of large ranges of radioactivity concentrations. This system could be particularly useful in experiments using tracers labelled with short half-live positron emitters such as "C, but linearity of response with other positron emitters than ${ }^{18} \mathrm{~F}$ still needs to be established. Our quantification results, with both methods and expressed in \% $\mathrm{ID} / \mathrm{g}$, are close to those previously reported (4). Discrepancy can be related to different experimental conditions such as anaesthesia versus waking state, type of anaesthetic compound, ways of data analysis (autoradiographic versus tissue counting). In human PET studies, we found a value of $0.0022 \% \mathrm{ID} / \mathrm{g}(2.3 \% \mathrm{ID} / 1)$ in the frontal cortex at $90 \mathrm{~min}$ after an injection of about $1 \mathrm{mCi} / 10 \mathrm{~kg}$. This leads to $0.75 \% \mathrm{ID} / \mathrm{g}$ if normalized to a body weight of $200 \mathrm{~g}$, a value which is very close to the values obtained in our in vivo rat experiment. Our preliminary result on the use of $\left[{ }^{14} \mathrm{C}\right]$ carbone microscales on autoradiographic film to allow ${ }^{\mathrm{I}} \mathrm{F}_{\mathrm{F}}$ activity quantification in rat brain without requiring brain homogenates standards indicates that, for a ligand such as $\left[{ }^{\mathrm{I}} \mathrm{F}\right]$ altanserin with a specific binding of $30 \mathrm{pmol} / \mathrm{g}$, a minimal specific activity of $2 \mathrm{Ci} / \mathrm{mmol}$ would be necessary to produce autoradiographic images in the range of the $\left[{ }^{14} \mathrm{C}\right]$ carbone microscales available and with the type of film used.

Competition and displacement experiments with ketanserin, a specific ligand for $5 \mathrm{HT}_{2}$ receptors, confirms the in vivo specific binding of $\left[{ }^{18} \mathrm{~F}\right]$ altanserin on $5 \mathrm{HT}_{2}$ receptors. Mesulergine shows no nanomolar affinity for the serotonin, dopamine or norepinephrine uptake sites and for adrenergic, histaminergic or dopaminergic receptors other than $5 \mathrm{HT}_{1} \mathrm{C}$ and $5 \mathrm{HT}_{2}$ receptors (5). Inhibition by mesulergine nearly completely prevents the in vivo uptake of $\left[{ }^{18} \mathrm{~F}\right]$ altanserin in the rat brain indicating the specificity of this ligand. The main concerns about the specificity of $5 \mathrm{HT}_{2}$ ligands like altanserin are possible interactions with the $\mathrm{D}_{2}$ dopaminergic and the $\alpha_{1}$ adrenergic receptors. Competition studies with sulpiride, a $\mathrm{D}_{2}$ antagonist, and prazosin, an $\alpha_{1}$ antagonist, showed no significant inhibition 
of $\left[{ }^{18} \mathrm{~F}\right]$ altanserin uptake by these compounds.

In conclusion, our experiment demonstrates that distribution of [ ${ }^{18} \mathrm{~F}$ ]altanserin in vivo binding in the rat brain precisely parallels the distribution of $5 \mathrm{HT}_{2}$ receptors previously reported in in vitro studies. Electronic imaging of brain slices may represent a practical approach for the in vivo quantification of $\mathrm{PET}$ radioligands binding in the rat brain.

\section{Aknowledgments}

This study has been supported by research grants 9.4503 .91 from the Belgian National Lottery, 3.4508.92, 3.4505.92 and 3.4533.94 from the Funds for Medical Scientific Research (FRSM, Belgium). Franqoise Biver is a research fellow of the National Funds for Scientific Research (FNRS, Belgium). We gratefully acknowledge the help in autoradiographic data analysis provided by Prof. B. Maziere and Mrs. M. Ottaviani from the Service Hospitalier Frederic Joliot (Orsay, France). We thank janssen Pharmaceutica for the gift of altanserin.

\section{References}

[1]. Appel N. M., Mitchell W. M., Garlick R. K,, Glennon R. A., Teitler M. and De Souza E. B. (1990) Autoradiographic characterization of $( \pm)-1-\left(2,5-\right.$ dimethoxy-4-[ ${ }^{125}$ I] iodophenylO-2-amino-propane $\left(\left[{ }^{125} \mathrm{I}\right] \mathrm{DOIO}\right.$ binding to $5-\mathrm{HT}_{2}$ and 5 -HT $\mathrm{Hc}_{\mathrm{c}}$ receptors in rat brain. ]. Pharmacol. Exp. Ther. 255, 843-857.

[2]. Biver F., Goldman S., Luxen A., Monclus M., Forestini M., Mendlewicz J. and Lotstra F. (1994) Multi-compartmental study of $\left[{ }^{18} \mathrm{~F}\right]$ altanserin binding to brain $5 \mathrm{HT}_{2}$ receptors in human using positron emission tomography. Eur. ]. Nucl. Med. 21, 937946.

[3]. Johnson E. W, Sybirska E., Al-Tikriti M. and Innis R. B. (1991) Calibration of [ ${ }^{123}$ I]Iodine-labeled tissue standards for autoradiographic studies. Af.pl. Radiat. hot. 42, 1199-1201.

[4]. Lemaire C., Cantineau R., Guillaume M., Plenevaux A. and Christiaens L. (1991) Fluorine-18-altanserin: a radioligand for the study of serotonin receptors with PET: radiolabeling and in vivo biologic behavior in rats. J. Nucl. Med. 32, $2266-72$.

[5]. Leysen J. E. (1992) 5HT2-receptors: location, pharmacological, pathological and physiological role. In: Serotonin receptor subtypes: pharmacological significance and clinical implications (Edited by Langer S. Z., Brunello N., Racagni G. and Mendlewicz J.) pp 31-43. Karger, Basel.

[6]. Malgouris C., Flamand F. and Doble A. (1993) Autoradiographic studies of RP62203, a potent 5-HT 2 receptor antagonist. In vitro and ex vivo selectivity profile. Eur. J. Pharmacol 233, 29-35.

[7]. Mengod G., Pompeiano M., Martinez-Mir I. and Palacios J. M. (1990) Localization of the mRNA for the 5-HT 2 receptor by in situ hybridization histochemistry. Correlation with the distribution of receptors sites. Brain Res. 524, 139-143.

[8]. Monclus M., Masson C, Luypaert P. J., Van Naemen J., Ledent E. and Luxen A. (1993) Nucleophilic [ ${ }^{18}$ F] radiofluorination using microwave cavity: application to $\left[{ }^{18} \mathrm{~F}\right] \mathrm{FDG}$ and $\left[{ }^{18} \mathrm{~F}\right]$ altanserin synthesis. Eur. J. Nucl. Med. 20 , 1000. [9]. Pazos A., Probst A. and Palacios J. M. (1987) Serotonin receptors in the human brain. IV. Autoradiographic mapping of serotonin-2 receptors. Neuroscience 21, 123-139. 